\title{
ポリカチオン化ホスファチジン酸コンジュゲートの合成と 遺伝子導入キャリャーとしての機能評価
}

\author{
出羽 毅久*1,† · 家田 由佳利*1 · 森田 一行*1 · 吉田 清貴*1 \\ Li WANG*2 ${ }^{* 2}$ Robert C. MACDONALD*2 ·飯田 浩史*3 \\ 山下 啓司 ${ }^{* 1} \cdot$ 奥 直人*4 $\cdot$ 南後 守*1
}

（受付 2004 年 5 月 31 日・審査終了 2004 年 8 月 20 日）

\begin{abstract}
要 旨 非ウイルス系遺伝子導入キャリヤーとして，スペルミシン，スペルミン，およびポリエチレン イミン(平均分子量 1800) をカチオン部位にもつシパルミトイルホスファチシン酸誘導体を新規に合成し た， $\beta$-ガラクトシダーゼアッセイにより，これらが遺层子導入効果を有することがわかった。これらの ポリカチオン化リン脂質は水溶液中では 90〜200 $\mathrm{nm}$ 程度の集合体を形成しており，これらが DNA との 複合体を形成することを原子間力顕微鏡により直接観察した。遺层子導入効果は，その複合体サイズが小 さいものほど高いことが認められた.
\end{abstract}

\section{1 緒 言}

遺伝子治療では，より高効率で安全性の高い遺伝子導 スシステムの開発が重要となっている1). 遺伝子導入の ためのキャリヤーとして, アデノウイルスなどに代表さ れるウイルス系, およびカチオン性脂質などによる非ウ イルス系に大別される. 導入効率では前者が勝っている むのの, 安全性, 簡便性, さらに大量生産という点では 後者に大きな利点があり, 多くの非ウイルス系キャリ ヤーに関する報告がなされている2) 11).

カチオン性キャリヤーによる遺伝子輸送は，エンド ソーム経由の機構が考えられているが12)，その詳細は明 らかではない. 遺伝子導入のために有効なポリカチオ ン-DNA 複合体の多形現象 (ラメラ構造やへキサゴナル 構造)についてもこれまでに多く研究されてきた ${ }^{13) \sim 18)}$. また, 吉川らは, 蛍光および電子顕微鏡による観察か ら, シオクタデシルアミドグリシルスペルミン(DOGS) の集合体が DNA で覆われたヌクレオソーム状の構造を 形成し，これらがネットワーク状に集合することを示し た. そして，この集合体が効果的な遗伝子導入に寄与し

*1 名古屋工業大学大学院物質工学専攻 (严466-8555 名古屋 市昭和区御器所町)

*2 Department of Biochemistry, Molecular Biology, and Cell Biology, Northwestern University (Evanston, Illinois 60208 U.S.A.)

*3 名古屋市工業研究所 (拜456-0058 名古屋市熱田区六番町 三丁目 4-41)

*4 静岡県立大学薬学部 (恶422-8526 静岡市谷田 52-1)
ていると考察している13). しかし，現時点ではポリカチ オン-DNAの集合形態と遺伝子導入効率との関係はま たほとんど明らかではない。

筆者らはこれまでに，セチル化ポリエチレンイミン (cetyl-PEI)で修飾したポリカチオン化リポソーム(PCL) が高い遣伝子導入活性をもつことを報告してきた ${ }^{19)}$ 22). その中で，蛍光標識した脂質， cetyl-PEI, DNA を共焦 点レーザー顕微鏡で細胞内追跡することにより, cetylPEI が DNA との複合体となって核まで到達しているこ とを明らかにした22)。これは，エンドソームに取込まれ た DNA-PCL 複合体がサイトゾルを移動し, cetylPEI とDNA との複合体となって核に輸送されていると 考えられる. カチオン性リポソームによる遺伝子輸送の 鍵となるプロセスは核内への進入プロセスであると考え られており23)，カチオン性キャリヤーの DNA 凝集力お よびポリカチオン-DNA 複合体のサイズが遺伝子導入 効率に深く関与していると予想される24).

PEI はそれ自体で遺伝子導入キャリヤーとして用いら れているが，少なからず細胞毒性があり，また分子量分 布をもつため，薬物として認可を得ることが困難であ る、筆者らは前報において，新規なポリカチオンージア ルキルリン酸エステルを簡便な手法で合成し，これらが 遺伝子導入効果を有することを示した ${ }^{24)}$ ．本報では，天 然に存在するリン脂質である 1,2-シパルミトイルホス ファチシン酸(DPPA)の極性部位にポリカチオン部位 (スペルミシン，スペルミン，PEI(1800))を有する新規 なポリカチオン化リン脂質を簡便な方法で合成した 

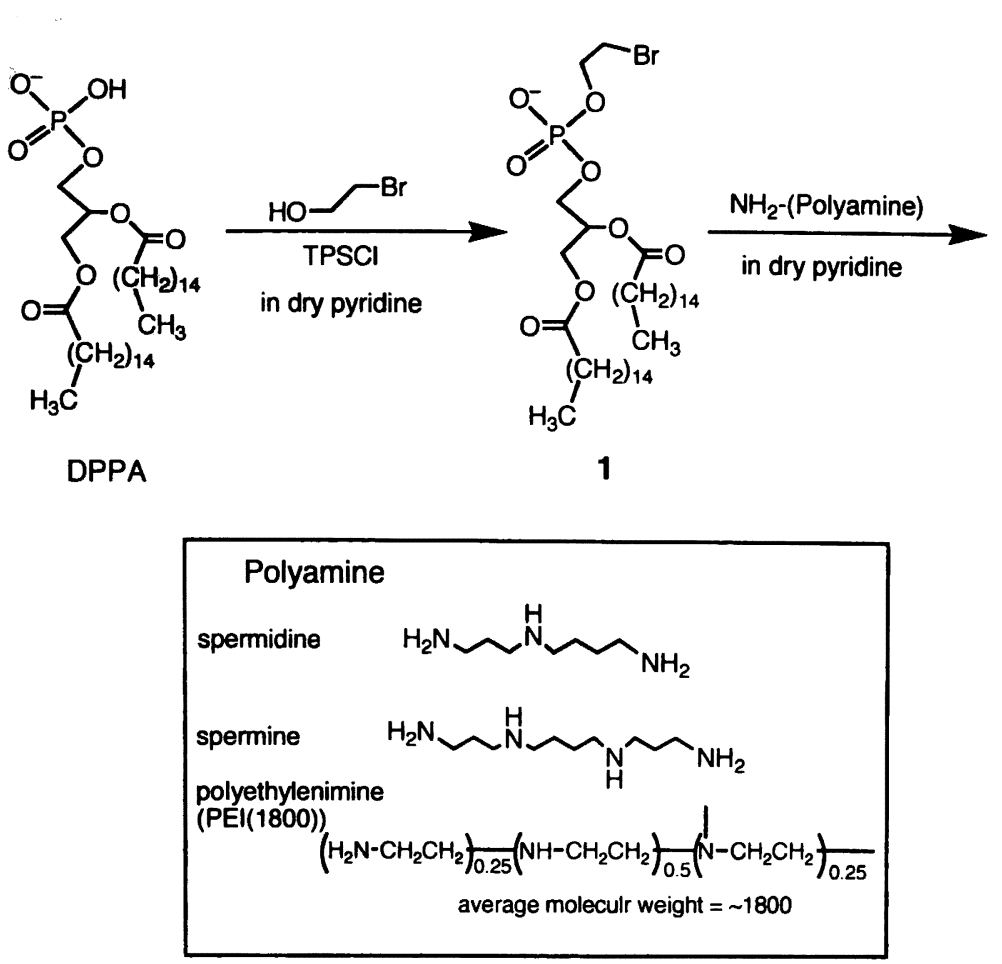

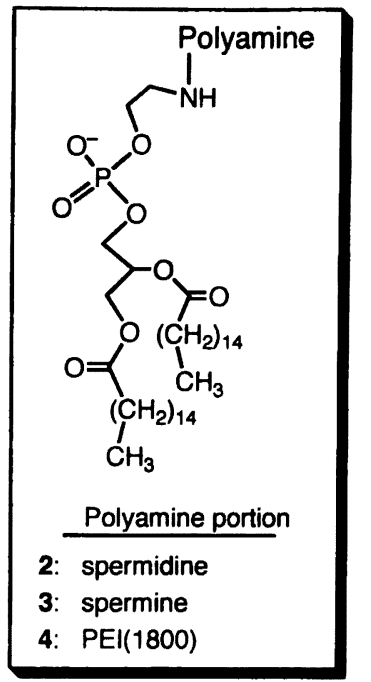

Scheme 1. Synthetic strategy for polycationic lipid conjugates via synthetic intermediate, 1.
(Scheme 1). 本手法を用いることで，疎水部位および カチオン性部位の異なる誘導体を容易に合成でき, 疎水 性一親水性のバランスを細かく制御することが可能であ る. 合成された 3 種類のポリカチオン化リン脂質の遺伝 子導入効率を $\beta$-ガラクトシダーゼアッセイによって評 価した．さらに，ポリカチオン化リン脂質-DNA 複合 体の形態観察を原子間力顕微鏡 (AFM)により行い, 導 入効率と形態との相関性について考察した.

\section{2 実験}

\section{1 諸種のポリカチオン化リン脂質合成}

2.1.1 1,2 ジパルミトイルグリセロリン酸ブロモエチ ルエステル(化合物 1)の合成

$15 \mathrm{mg}$ の DPPA $(22 \mu \mathrm{mol})$ を無水ピリシン $(0.5 \mathrm{~mL})$ 中 に溶かし，2-ブロモエタノール $10 \mu \mathrm{L}(127 \mu \mathrm{mol})$ と 1,3,5-トリイソプロピルベンゼンスルホニルクロライ ト (TPSCl $)^{25), 26)} 30 \mathrm{mg}(100 \mu \mathrm{mol})$ を加えた。窒素雾囲 気下室温で 5 時間かくはんした後, $0.15 \mathrm{~mL}$ の水を加え 反応を停止させた，溶媒を減圧留去後, 薄層クロマトグ ラフィー(展開溶媒 : クロロホルム/メタノール $=3 / 1)$ に より $R_{f}$ 値 $0.5 \sim 0.6$ の区分を回収し, 目的化合物 1 を 13 $\mathrm{mg}(17.6 \mu \mathrm{mol})$ 得た。収率は $80 \%$ であった。 ${ }^{1} \mathrm{H}$ NMR $\left(300 \mathrm{MHz}, \mathrm{CDCl}_{3}\right) \delta: 0.89(\mathrm{t}, 6 \mathrm{H}), 1.26(\mathrm{br} \mathrm{s}, 48 \mathrm{H})$, $1.57(\mathrm{~m}, 4 \mathrm{H}), 2.28(\mathrm{~m}, 4 \mathrm{H}), 3.50(\mathrm{~m}, 2 \mathrm{H}), 3.8-4.5(\mathrm{br}$, $6 \mathrm{H}), 5.25(\mathrm{~m}, 1 \mathrm{H}) .\left(\mathrm{C}_{37} \mathrm{H}_{71} \mathrm{O}_{8} \mathrm{PBr}^{79} \mathrm{Na}_{2}\right)+$ に対する
SIMS：理論値 799.4, 実測値 799.3.

\subsection{2 化合物 2 の合成}

反応容器中で無水ピリシンン $(0.5 \mathrm{~mL})$ 中にスペルミシ ン $8.5 \mathrm{mg}(58.5 \mu \mathrm{mol})$ を溶かし，無水ピリシン $(0.5 \mathrm{~mL})$ 中に溶解させた化合物 $1(16.4 \mathrm{mg} ; 21.1 \mu \mathrm{mol})$ を室温で 滴下した，窒素䨌囲気下室温で 24 時間かくはんし，容 媒留去後, アミノ化シリカゲル(富士シリシア化学(株)製： 100-200 mesh NH Chromatorex)を用いたカラムクロマ トグラフィー(溶離液 : クロロホルム/メタノール $=3 / 1$ ) で目的化合物 2 を $7.7 \mathrm{mg}$ 得た. 収率は $45 \%$ であった。 ${ }^{1} \mathrm{H}$ NMR $\left(300 \mathrm{MHz}, \mathrm{CDCl}_{3}\right) \delta: 0.88(\mathrm{t}, 6 \mathrm{H}), 1.25(\mathrm{~s}, 48$ H), 1.5-1.9 (br, $14 \mathrm{H}), 2.30(\mathrm{br}, 4 \mathrm{H}), 2.5-3.0(\mathrm{br}, 10$ H), $3.69(\mathrm{br}, 2 \mathrm{H}), 3.99(\mathrm{br}, 2 \mathrm{H}), 4.41(\mathrm{~m}, 2 \mathrm{H}), 5.25$ (br, $1 \mathrm{H})$. FT-IR $(\mathrm{KBr}) \vee\left(\mathrm{cm}^{-1}\right): 3299,2956,2918$, $2851,1729,1637,1558,1466,1217,1070 .\left(\mathrm{C}_{44} \mathrm{H}_{91} \mathrm{~N}_{3} \mathrm{O}_{8}\right.$ P) + に対する SIMS : 理論值 : 820.6, 分析値 : 820.6.

\subsection{3 化合物 3 の合成}

反応容器中で無水ピリシンン $(0.25 \mathrm{~mL})$ 中にスペルミン $10.3 \mathrm{mg}(51 \mu \mathrm{mol})$ を溶かし, 無水ピリジン $(0.75 \mathrm{~mL})$ 中 に溶解させた化合物 $1(16.4 \mathrm{mg} ; 21.1 \mu \mathrm{mol})$ を室温で滴 下した。窒素雾囲気下室温で 24 時間かくはんし，溶媒 留去後, 中性アルミナを用いたカラムクロマトグラフ ィー(溶離液 : クロロホルム/メタノール $=3 / 1$ ) で目的化 合物 3 を $9.4 \mathrm{mg}$ 得た。収率は $51 \%$ であった。 ${ }^{1} \mathrm{H}$ NMR $\left(300 \mathrm{MHz}, \mathrm{CDCl}_{3}\right) \delta: 0.88(\mathrm{t}, 6 \mathrm{H}), 1.25(\mathrm{~s}, 48 \mathrm{H}), 1.4-$ 
$1.9(\mathrm{br}, 16 \mathrm{H}), 2.30(\mathrm{br}, 4 \mathrm{H}), 2.5-3.0(\mathrm{br}, 16 \mathrm{H}), 3.95$ (br, $2 \mathrm{H}), 4.15$ (br, $2 \mathrm{H}), 4.45(\mathrm{~m}, 2 \mathrm{H}), 5.25$ (br, $1 \mathrm{H})$. FT-IR $(\mathrm{KBr}) v\left(\mathrm{~cm}^{-1}\right): 3400,3308,2947,2918,2850$, $1737,1640,1563,1468,1219,1063 .\left(\mathrm{C}_{47} \mathrm{H}_{98} \mathrm{~N}_{4} \mathrm{O}_{8} \mathrm{P}\right)+$ に対 する SIMS : 理論値 : 877.7, 分析值 : 877.7.

\subsection{4 化合物 4 の合成}

数平均分子量 1800 のポリエチレンイミン ((株) 日本触 媒製 : PEI(1800))はあらかじめ限外ろ過 (Amicon : 分子 量カット 500)により精製したものを用いた．反応容器 中で無水ピリシン $(0.5 \mathrm{~mL})$ 中に PEI(1800) $11.6 \mathrm{mg}(6.4$ $\mu \mathrm{mol})$ を溶かし，無水ピリジン $(0.3 \mathrm{~mL})$ 中に溶解させた 化合物 1 (5 mg; $6.4 \mu \mathrm{mol})$ を室温で滴下した。窒素雾囲 気下室温で 24 時間かくはんし, 溶媒留去後, 中性アル ミナを用いたカラムクロマトグラフィー(溶離液 : クロ ロホルム/メタノール =3/1) で目的化合物 4 を $5.3 \mathrm{mg}$ 得 た. 収率は $32 \%$ であった。 ${ }^{1} \mathrm{H}$ NMR $\left(300 \mathrm{MHz}, \mathrm{CDCl}_{3}\right)$ $\delta: 0.86(\mathrm{t}, 6 \mathrm{H}), 1.24(\mathrm{~s}, 48 \mathrm{H}), 1.60(\mathrm{~m}, 4 \mathrm{H}), 2.32$ (br, $4 \mathrm{H}), 2.35-3.1$ (br, $184 \mathrm{H}), 3.25-4.58(\mathrm{br}, 37 \mathrm{H}), 5.19$ (br, $1 \mathrm{H})$. FT-IR $(\mathrm{KBr}) v\left(\mathrm{~cm}^{-1}\right): 3407,3306,2950$, 2923, 2850, 1737, 1640, 1562, 1468, 1219, 1063.

\section{2 測定}

$\beta$-ガラクトシダーゼアッセイによる遺伝子導入効果 の評価, ColE1 プラスミドへのエチジウムブロミド $(\mathrm{EtBr})$ のインターカレーションによる蛍光測定, ポリ カチオン化リン脂質と ColE1 プラスミドとの複合体の 動的光散乱測定, および原子間力顕微鏡観察は既報の方 法により行った ${ }^{24)}$.

\section{3 結果と考察}

\section{1 ポリカチオン化リン脂質(2-4)の合成}

Scheme 1 で示すように, リン酸エステル部位をブロ モエチル化した中間体 1 と, 諸種のポリカチオンの 1 級 アミンを反応させることにより得だ. 縮合剂としてTPSCl を用いることにより容易に得る ことができる．前報では，ジチルリン酸エステルとの 2-ブロモエタノールの付加物は得られず，代わりにシ セチルリン酸エステルの酸無水物が生成することを示し た24). DPPA では酸無水物の生成は確認されなかった.

\section{2 遭伝子導入効果}

Figure 1 に $\beta$-ガラクトシダーゼアッセイによって調 ベられた化合物 2-4の遗伝子導入効果を示した. 参照化 合物として，市販の遺伝子導入試剤である O-ethyl DOPC (E-DOPC) ${ }^{5)}$ を用いたところ $0.1 \mathrm{mU} /$ well の活性 を示した. E-DOPC と比較して，約 20〜40\%程度の遺

\footnotetext{
*1 スペルミシンは非対称な分子であり，二つの一級アミンは 非等価であるため, スペクトル的に 2 種類のスペルミシン 付加物を区別することは困難である.
}

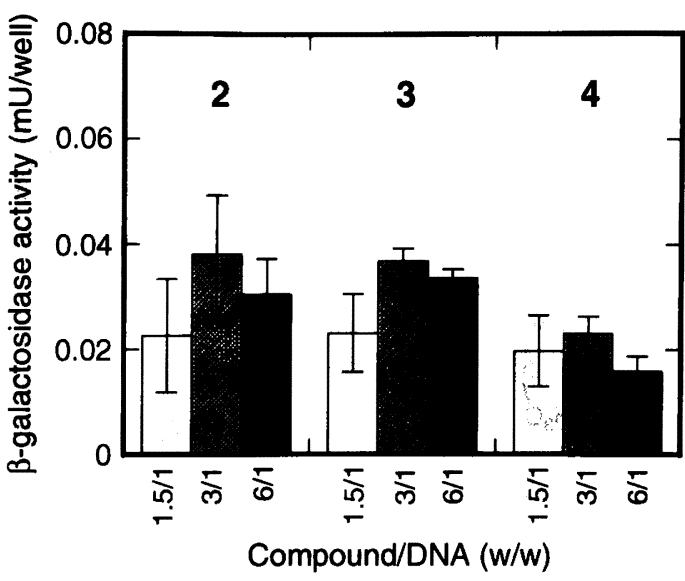

Figure 1. Transfection efficacy of polycationic lipid conjugates 2-4 on vascular smooth mascle cells in the absence of serum. The ratios of compound $/ \beta$-galactosidase plasmid DNA $(\mathrm{w} / \mathrm{w})$ were $1.5 / 1,3 / 1$, and $6 / 1$, respectively.

伝子導入効果が認められた。化合物 2-4 の構成成分 (DPPA, スペルミシン, スペルミン, PEI (1800)) 単独 では遺伝子導入効果は極めて低い $(0.1 \sim 1 \%)$ ことから， ポリカチオン部位と脂質部位のコンジュゲートにより 遺伝子導入効果が発現していると考えられた。化合物/ DNA 比 1.5/1 6/1 (w/w)において, 導入効率は誤差 範囲内で差異は認められなかった．化合物 2-4におい て，わずかではあるが活性の違いが見られ，2２3>4で あった.

\subsection{ColE1 DNA とポリカチオン化リン脂質との複合 体形成}

ColE1 DNA（6646 bp)にインターカレートしたエチ ジウムブロミド $(\mathrm{EtBr})$ の萤光強度が, ポリアミンと の複合体形成により減少していく様子を Figure 2 に示 した．ポリアミン類(スペルミシン，スペルミン， PEI (1800)）単独では, 電荷比 N/P（Nはポリアミン中の窒 素原子数, P は DNA 中のリン酸基数)が増加するに従 って, EtBr の蛍光強度が減少した(Figure 2A)．その傾 向は 1 分子あたりの窒素原子数の多いむのほど顕著であ る $(\mathrm{PEI}(1800)>$ スペルミン>スペルミシン)ことから， カチオンの電荷密度が高いものほど DNA との相互作用

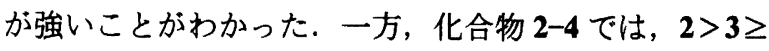
4 となり，DPPA とのコンシュゲート化により複合体形 成能が，それぞれのポリアミン単独系とは逆の傾向を示 した(Figure 2B).

Table 1 に動的光散乱 (DLS)により求められた化合物 2-4の粒子径を示し, Figure 3（A-C)にこれら粒子の AFM 像を示した．DLS 測定から見積もられた粒子径と AFMによって観察された粒子サイズはほほ一致するこ とがわかった. Figure 3 から，2および 3 では約 $100 \mathrm{~nm}$ 程度，4では約 $200 \mathrm{~nm}$ 程度の集合体が見られた．分子 
の形状は逆コーン型であるので，これらはおそらくミセ ル状の集合物であると考えられる.

Figure 3DにColE1 DNAのAFM 像を示した。部分 的にコイル状の，直径 300〜 400 nm の環状構造が観測 された. ColE1 DNA と化合物 2-4 との複合体の AFM 像を Figure 3 (G-I)にそれそれ示した. 球状〜棈円状の 集合物がそれぞれ観察され，これらのサイズは2（129 $\mathrm{nm})<3(172 \mathrm{~nm})<4(201 \mathrm{~nm})$ であった. より小さな複
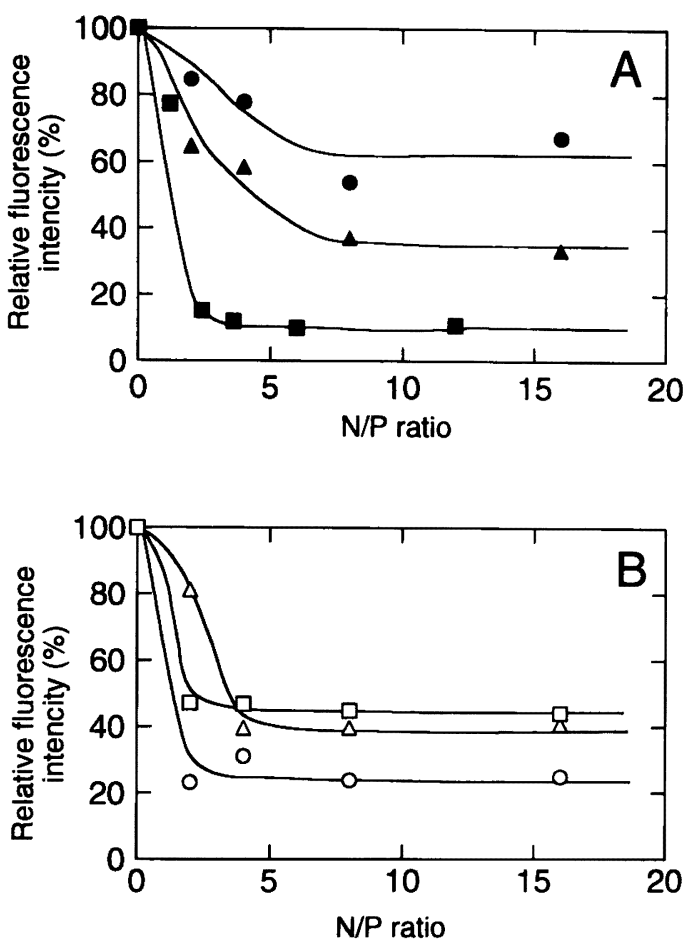

Figure 2. Changes in fluorescence intensity of ethidium bromide intercalated into Col E1 plasmid DNA/polyamine compounds: (A), spermidine $(\mathbf{O})$, spermine $(\boldsymbol{\Delta})$, and PEI (1800) $(\square)$; (B), $2(\bigcirc), 3(\triangle)$, and $4(\square)$. Displacement of ethidium bromide, $\mathrm{EtBr}$, intercalated into DNA was measured at $\mathrm{EtBr} /$ nucleotide $=50 / 1(\mathrm{~mol} / \mathrm{mol})$ with varying polyamine contents. EtBr fluorescence at $590 \mathrm{~nm}$ (excitation wavelength: $260 \mathrm{~nm}$ ) was recorded to obtain the relative fluorescence intensity, $I / I_{0}$, where $I$ and $I_{0}$ are fluorescence intensities in the presence and the absence of polyamine derivatives, respectively.
合体サイズとなるポリカチオン性脂質ほどより DNA を 凝縮する効果があると考えられ，この複合体サイズ順序 は EtBrの蛍光強度から調へた ColE1 DNA との複合体 形成能をおおよそ反映している．観測された複合体サイ ズと遺伝子導入効率との相関を見ると, より小さな複合 体サイズとなるポリカチオン化脂質ほど高い遺伝子導入 効率を示している.この傾向は前報での結果 ${ }^{24)}$ と一致し ている.

Figure 3E と3F はそれぞれ ColE1 DNA とスペルミン および PEI(1800) との複合体の AFM 像である．スペル ミン(3E)では DNA の凝縮が不完全な構造物 ( 3 $\mu \mathrm{m})$ となった．PEI（1800）（3F）では， $416 \times 218 \mathrm{~nm}$ (高さ 〜22 nm)の集合物が見られた。化合物(3および 4) と DNAの方がより凝縮能が明らかに高いことから, 疎水 性部位が DNA の凝縮に必要であることがわかった。

前報では，ジセチルリン酸エステル $(\mathrm{DCP})$ と $\mathrm{P}-\mathrm{N}$ 結 合を介して結合したスペルミシン， スペルミン，PEI (1800)について同様の検討を行い, DNAの凝縮能およ び遺伝子導入効率は PEI(1800)-DCP コンジュゲートが もっと高いことがわかっだ24). 本報のDPPA と結合し たポリアミン類は，これとは逆の結果となった．その理 由は現在明らかではないが，DCP とDPPAでの微妙な 疎水性一親水性バランス, カチオン部位と疎水性部位の 間のわずかなスペーサーの効果などが，DNAの凝縮能 に寄与していることが考えられる．以上の結果から， DNAの凝縮能が高いものほど高い遺伝子導入効果があ ることが明らかとなった. 本報で高い遺伝子導入効率を 示したものはすべて生体が本来有しているもの(DPPA, スペルミシン， スペルミン)で構成されており，低毒性 を示すことが期待される. また, アシル鎖長の異なるも のを容易に合成可能であることから，柾水性一親水性バ ランスを変化させることにより, DNA との複合形態を 系統的に調べることも可能である. ポリカチオン化リン 脂質-DNA 複合体の形態が遺伝子導入に及ほす影響に ついて，さらなる知見が得られると期待される.

Table 1. Estimated size and shape of 2-4 and complexes with ColE1 DNA suspended in aqueous solution ${ }^{\mathrm{a})}$

\begin{tabular}{|c|c|c|c|c|c|c|}
\hline \multirow{3}{*}{$\begin{array}{c}\text { Compound } \\
2\end{array}$} & \multicolumn{2}{|c|}{$\operatorname{DLS}(\mathrm{nm})$} & \multicolumn{4}{|c|}{$\mathrm{AFM} /$ width $(\mathrm{nm})$ and height $(\mathrm{nm})^{\mathrm{b})}$} \\
\hline & \multirow{2}{*}{$\begin{array}{c}\text { Conjugate alone } \\
90 \pm 8\end{array}$} & \multirow{2}{*}{$\frac{\text { Complex with DNA }}{140 \pm 40}$} & \multicolumn{2}{|c|}{ Conjugate alone } & \multicolumn{2}{|c|}{ Complex with DNA } \\
\hline & & & 96 & 24 & 129 & 21 \\
\hline 3 & $106 \pm 41$ & $109 \pm 40$ & 112 & 16 & 172 & 37 \\
\hline 4 & $218 \pm 35$ & $205 \pm 39$ & 201 & 12 & 201 & 17 \\
\hline
\end{tabular}

a) The ratio of polyamine conjugate/DNA was $3 / 1(w / w)$. Complexation of polyamine conjugate with DNA was carried out in water. b) Sample solution was spreaded on a mica surface and dried. AFM images were obtained under dry condition. Width and height of the complexes were estimated from the AFM images in Figure 3. 

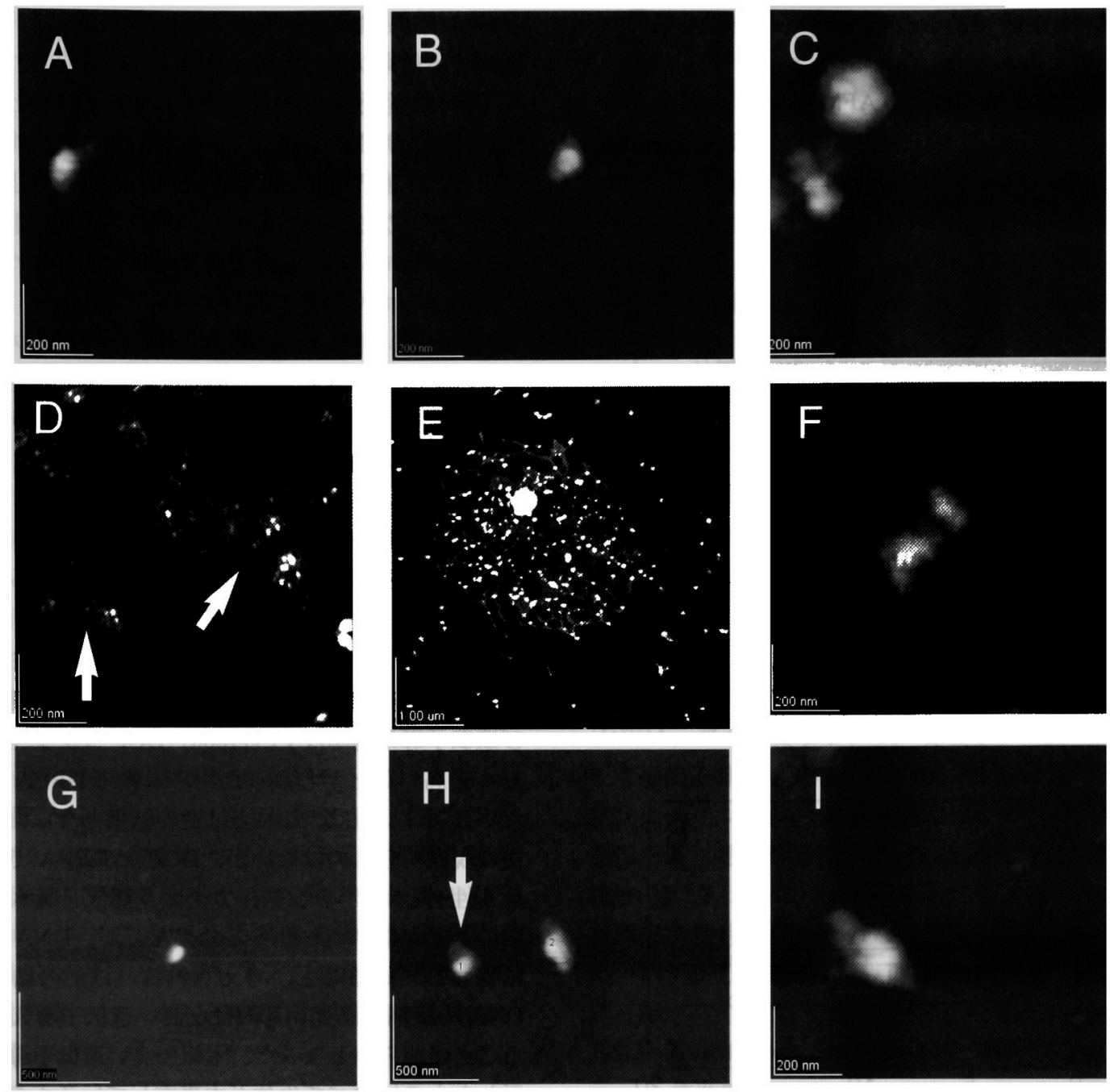

Figure 3. AFM images of arrays of compounds: 2 (A), 3 (B), 4 (C), ColE1 DNA alone (D), spermineColE1 DNA (E), PEI(1800)-ColE1 DNA (F), 2-ColE1 DNA (G), 3-ColE1 DNA (H), 4-ColE1 DNA (I). The compound was suspended in distilled water and then dropped onto a mica surface by spin coating. The polyamine/DNA ratio was $3 / 1$ (w/w). All scale bars represent (A) 200, (B) 200, (C) 200, (D) 200, (E) 1000, (F) 200, (G) 500, (H) 500, and (I) $200 \mathrm{~nm}$, respectively. The object indicated by the arrow is discussed in the text. These AFM images of the conjugate-DNA complexes were acquired with a JEOL JSPM-4210 equipped with a cantilever (MikroMasch, type A: $110 \mathrm{~mm}, 7.5 \mathrm{~N} / \mathrm{m}$ ), using the discrete contact mode (AC mode).

謝 辞 科学技術振興機構さきがけタイプ(組織化と機能領 域)および竹本油脂 (株)からの部分的資金援助に感謝いたし ます。

\section{文献}

1) M. A. Kay, M. D. Liu, and P. M. Hoogerbrugge, Proc. Natl. Acad. Sci. U.S.A., 94, 12744 (1997).

2) D. D. Lasic, "Liposomes in Gene Delivery", CRC Press, Boca Raton, FL (1997).

3) A. D. Miller, Angew. Chem., Int. Ed., 37, 1768 (1998).

4) O. Meyer, D. Kirpotin, K. Hong, B. Sternberg, J. W. Park, M. C. Woodle, and D. Papahadjopoulos, J. Biol. Chem., 273, 15621 (1998).
5) R. C. MacDonald, G. W. Ashley, M. M. Shida, V. A. Rakhmanova, Y. S. Tarahovsky, D. P. Pantazatos, M. T. Kennedy, E. V. Pozharski, K. A. Baker, R. D. Jones, H. S. Rosenzweig, K. L. Choi, R. Qiu, and T. J. McIntosh, Biophys. J., 77, 2612 (1999).

6) M. Nakanishi and A. Noguchi, Adv. Drug Delivery Rev., 52, 197 (2001).

7) J.-P. Behr, Bioconjugate Chem., 5, 382 (1994).

8) A. Kichler, K. Mechtler, J.-P. Behr, and E. Wagner, Bioconjugate Chem., 8, 213 (1997).

9) S. Bhattacharya and P. V. Dileep, Bioconjugate Chem., 15, 508 (2004).

10) T. Nagasaki, M. Hojo, A. Uno, T. Satoh, K. Koumoto, M. Mizu, K. Sakurai, and S. Shinkai, Bioconjugate Chem., 15, 249 (2004).

11) T. Nakai, T. Kanamori, S. Sando, and Y. Aoyama, J. Am. Chem. Soc., 125, 8465 (2003). 
12) I. Wrobel and D. Collins, Biochim. Biophys. Acta, 1235, 296 (1995).

13) Y. Yoshikawa, N. Emi, T. Kanbe, K. Yoshikawa, and H. Saito, FEBS Lett., 396, 71 (1996).

14) J. O. Rädler, I. Koltover, A. Jamieson, T. Salditt, and C. R. Safinya, Langmuir, 14, 4272 (1998).

15) A. Martin-Herranz, A. Ahmad, H. M. Evans, K. Ewert, U. Schulze, and C. R. Safinya, Biophys. J., 86, 1160 (2004).

16) M. T. Kennedy, E. V. Pozharski, V. A. Rakhmanova, and R. C. MacDonald, Biophys. J., 78, 1620 (2000).

17) R. Koynova and R. C. MacDonald, Biophys. J., 85, 2449 (2003).

18) E. Raspaud, B. Pitard, D. Durand, O. Aguerre-Chariol, J. Pelta, G. Byk, D. Scherman, and F. Livolant, J. Phys. Chem. B., 105, 5291 (2001).

19) Y. Yamazaki, M. Nango, M. Matsuura, Y. Hasegawa, M. Hasegawa, and N. Oku, Gene Therapy, 7, 1148 (2000).

20) N. Oku, Y. Yamazaki, M. Matsuura, M. Sugiyama, M. Hasegawa, and M. Nango, Adv. Drug Delivery Rev., 52, 209 (2001).
21) M. Matsuura, Y. Yamazaki, M. Sugiyama, M. Kondo, H. Ori, M. Nango, and N. Oku, Biochim. Biophys. Acta, 1612, 136 (2003).

22) M. Sugiyama, M. Matsuura, Y. Takeuchi, J. Kosaka, M. Nango, and N. Oku, Biochim. Biophys. Acta, 1660, 24 (2004).

23) H. Harashima, Y. Shinohara, and H. Kiwada, Eur. J. Pham. Sci., 13, 85 (2001).

24) T. Dewa, K. Ieda, K. Morita, Li Wang, R. C. MacDonald, K. Iida, K. Yamashita, M. Oku, and M. Nango, Bioconjugate Chem., 15, 824 (2004).

25) M. Uragami, Y. Miyake, and S. L. Regen, Langmuir, 16, $3491(2000)$

26) T. Tanaka, T. Sakata, K. Fujimoto, and M. Ikehara, Nucleic Acids Res., 15, 6209 (1987).

\section{[Notes]}

Novel Polycationic Phospholipid Conjugates for Gene Carriers

Takehisa Dewa, ${ }^{* 1},{ }^{+}$Yukari Ieda, ${ }^{* 1}$ Kazuyuki Morita, ${ }^{* 1}$ Kiyotaka Yoshida, ${ }^{* 1}$ Li Wang, ${ }^{* 2}$ Robert C. MAcDonald, ${ }^{* 2}$ Kouji IIDA, ${ }^{* 3}$ Keiji YamAShita, ${ }^{* 1}$ Naoto OKu, ${ }^{* 4}$ and Mamoru Nango*1

${ }^{* 1}$ Materials Science and Engineering, Nagoya Institute of Technology (Gokiso-cho, Showa-ku, Nagoya 466-8555, Japan)

${ }^{* 2}$ Department of Biochemistry, Molecular Biology, and Cell Biology, Northwestern University, (Evanston, Illinois 60208, USA)

${ }^{* 3}$ Nagoya Municipal Industrial Research Institute (3-4-41 Rokuban-cho, Atsuta-ku, Nagoya 456-0058, Japan)

${ }^{* 4}$ University of Shizuoka, School of Pharmaceutical Science (52-1 Yoda, Shizuoka 422-8526, Japan)

Three types of polycationic phospholipids conjugates were synthesized to develop a novel nonviral gene carrier. The conjugates composed of a polyamine portion: spermidine, spermine or polyethylenimine (PEI), and a phospholipid portion: dipalmitoylphosphatidic acid (DPPA) were synthesized via a synthetic intermediate, ethylbrominated DPPA. The polycationic lipids exhibited moderate transfection efficacy evaluated by $\beta$-galactosidase assay. These conjugates form a micelle-like assembly in aqueous solution, whose sizes are in the range of $90 \sim 220 \mathrm{~nm}$. The formation of the conjugate-DNA complex was observed by using atomic force microscopy (AFM). The AFM images revealed that the conjugate-bearing spermidine, which showed the most efficient transfection, enables one to form a compact complex $(\sim 130 \mathrm{~nm}$ in width) with DNA, while the conjugate-bearing PEI, which showed a less efficient transfection, forms a large complex $(\sim 200 \mathrm{~nm})$ with DNA.

KEY WORDS Polycationic Lipid / Polyamine / Gene Transfer / Compaction / AFM /

(Received May 31, 2004: Accepted August 20, 2004)

[Kobunshi Ronbunshu, 61(12), 634-639 (2004)]

\footnotetext{
+ PRESTO, JST
} 